\title{
Bimbingan dan Konseling Bagi Orangtua Anak Usia Dini Berkebutuhan Khusus (ABK)
}

\author{
Melda Rumia Rosmery Simorangkir \\ meldasimorangkir82@gmail.com \\ Universitas Kristen Indonesia
}

\begin{abstract}
A happiness when a woman in a family gives birth. Moreover, the baby who was born has been waiting long enough. However, sometimes what is expected by humans is not always the same as what was presented by the creator. Then what if it turns out that children who are present in the family are special children? These children need special attention due to physical and mental disorders. Not a few parents must have children with special needs (ABK) confused, shocked or even blame each other. This is certainly not something that is expected from children. ABK requires education, attention, assistance, special learning methods. Thus ABK parents must get special assistance so that they can accept their child and educate the child with great attention and love. ABK parents must be assisted from early childhood, so that education and care are more optimal. Counseling for ABK parents is done so parents do not feel alone, not ashamed, willing to accept and have a great readiness to accompany their children in the future. The counselor is expected to be able to help ABK's parents by providing counseling services specifically to guide parents. The guidance also serves to help parents provide alternative education and therapy that can be given to children with special needs from an early age.

Keywords: children with special needs, counselling, and guidance
\end{abstract}

\begin{abstract}
ABSTRAK
Sebuah kebahagian ketika seorang perempuan dalam sebuah keluarga melahirkan. Apalagi buah hati yang dilahirkan telah ditunggu cukup lama. Namun, terkadang apa yang diharapkan manusia tidak selalu sama dengan apa yang dihadirkan oleh pencipta. Lalu bagaimana apabila ternyata anak yang hadir dalam keluarga adalah anak yang special?. Anak tersebut memerlukan perhatian khusus baik disebabkan kelainan fisik maupun mental. Tidak sedikit Orangtua harus anak berkebutuhan khusus (ABK) mengalami kebingungan, kaget atau bahkan saling menyalahkan. Hal ini tentu bukan hal yang diharapkan dari anak. ABK memerlukan pendidikan, perhatian, bantuan, metode belajar khusus. Demikian orangtua $A B K$ harus mendapatkan pendampingan khusus agar mereka bisa menerima anak mereka dan mendidik anak tersebut dengan penuh perhatian dan cinta yang besar. Orangtua $A B K$ harus dibantu sejak anak usia dini, agar pendidikan dan pengasuhan lebih optimal. Konseling bagi orangtua ABK dilakukan agar orang tua tidak merasa sendiri, tidak malu, mau menerima dan memiliki kesiapan hati yang besar untuk mendampingi anak mereka di kemudian hari. Konselor di harapkan mampu menolong orang tua ABK dengan memberikan layanan-layan konseling khususnya membimbing orangtua. Bimbingan tersebut juga berfungsi untuk membantu orangtua memberikan alternatif pendidikan dan terapi yang dapat diberikan pada anak berkebutuhan khusus sejak usia dini.
\end{abstract}

Kata kunci: anak berkebutuhan khusus konseling, dan bimbingan 


\section{PENDAHULUAN}

Anak yang lahir di Indonesia sangat beragam tidak hanya anak-anak regular yang biasa bersekolah di sekolah umumnya.Tidak jarang kita mendapati anak yang ada di sekitar kita ternyata anak yang unik dan istimewa. Ada banyak kasus didapati seorang anak tidak berkembang optimal layaknya anak lainnya. Orang tua tidak mau ambil resiko lalu membawa anak mereka kepada dokter tumbuh kembang untuk mengetahui keadaan anak yang mereka miliki. Jamaris, 2013 (dalam Melda, 2019: 5) individu (dalam hal ini termasuk anak) dikatakan berkebutuhan khusus apabila didapati ciri-ciri khusus. Dalam perkembangannya terlihat begitu berbeda dengan anak normal lainnya penyimpangan dalam perkembangan sendiri bisa penyimpangan intelegensi yang ternyata di bawah normal yang bisa dikenal dengan retardasi mental, atau intelegensi di atas anak-anak normal yang biasa disebut superior dan gifted. Setiap anak pada saranya memiliki potensi yang berbeda-beda, baik anak umumnya di sekitar kita maupun anak berkebutuhan khusus. Potensi-potensi tersebut dapat dikembangkan untuk belajar, dalam hal ini organ yang berperan sangat besar adalah otak. Banyak cara yang bisa dilakukan untuk melakukan pengecekan terhadap fungsi organ tersebut dengan melakukan aktivitas-aktivitas. Sebelum aktivitas tentu anak dilihat dulu kelengkapan organnya, lalu melihat apakah berfungsi dengan baik atau berfungsi namun sangat lemah. Inilah yang disebut dengan ketunaan atau penyimpangan perkembangan fisik. Ketika anak didapati dengan kebutuhan yang permanen seperti ini pendidik, pengasuh dan orang tua diharapkan mampu membantu dengan optimal. Penyimpangan permanen lain juga bisa didapati pada anak, seperti penyimpangan perilaku, penyimpangan perkembangan visual, penyimpangan auditori, dan penyimpangan intelegensi. Selain penyimpangan permanen terdapat juga penyimpangan tidak permanen pada anak berkebutuhan khusus, organ tubuh lengkap namun tidak optimal fungsinya dikarenakan tidak mendapatkan asupan gizi yang cukup. Bimbingan dan konseling bagi orangtua anak berkebutuhan khusus sangat diperlukan untuk membantu orang tua anak berkebutuhan khusus mengenal diri anak secara spesifik dan menemukan kebutuhan dan hambatan anak secara menyeluruh. Bimbingan yang dapat dilakukan pada orangtua anak berkebutuhan khusus antara lain bimbingan belajar, bimbingan sosial, dan bimbingan karir. Hal ini sangat diperlukan agar orang tua dapat membimbing anak dalam belajar, dalam mengajarkan sosialisasi pada anak, dan membantu anak untuk menentukan karirnya di masa yang akan datang.

Berangkat dari permasalahan yang dihadapi orangtua anak berkebutuhan khusus yang beragam, mulai dari mempersiapkan kelahiran, pengasuhan dan pendidikan. Diharapkan orang tua mendapatkan kekuatan dan kaya akan pengetahuan untuk membesarkan anak usia dini. Masalah keluarga merupakan gejala interpersonal. Kondisi 
emosi salah satu anggota keluarga berpengaruh pada setiap anggota yang lain. Bila satu anggota keluarga merasa tidak enak/discomfort, maka hal ini akan mempengaruhi anggota lainnya. Kondisi keluarga dapat dianalogikan dengan kondisi individu dalam keadaan homeostasis. Jadi dalam konseling/terapi, keadaan homeostasis struktur keluarga ini, anakanak merupakan emotional product dari orang tua.

\section{PEMBAHASAN}

Bimbingan konseling adalah usaha untuk membantu individu mengembangkan diri secara optimal sesuai dengan tahap perkembangan dan predisposisi yang dimilikinya (seperti kemampuan dasar dan bakat-bakatnya), berbagai latar yang ada (seperti latar belakang keluarga, pendidikan, status ekonomi), serta sesuai dengan tuntutan positif lingkunganya. Dalam bimbingan dan konseling orangtua anak usia dini berkebutuhan khusus dibantu memfasilitasi dan membantu anak usia dini berkebutuhan khusus dalam mengembangkan potensi/ tugas-tugas perkembangan secara optimal dan mengatasi permasalahan yang dihadapi anak usia dini, meliputi aspek kultural, pendidikan, psikologis, dan lingkungan,

Pendidikan inklusif yang telah dicanangkan melalui berbagai deklarasi dan diperkuat oleh Undang-undang No. 20 tahun 2003 Sisdiknas, mendorong semua pihak yang bergerak di bidang pendidikan untuk mewujudkannya. Pelaksanaan pendidikan inklusif harus dimulai sejak usia dini, untuk itu harus dimulai dari keluarga dan lembaga PAUD.

Pendidikan untuk semua (Education for All) mencanangkan bahwa setiap anak, termasuk anak dengan kebutuhan khusus (ABK) memiliki hak yang sama dalam memperoleh pendidikan di sekolah regular. Hal ini membuka kesempatan bagi mereka untuk belajar bersama dengan mereka yang tidak memiliki kebutuhan khusus. Mengingat jenis dan karakteristik serta faktor yang melatar belakangi anak berkebutuhan khusus sangat bervariasi, maka alternatif bantuan bimbingan dan konseling juga cenderung berbeda.

\section{Anak Berkebutuhan Khusus}

Jamaris, 2013 (dalam Melda, 2019: 5) individu disebut berkebutuhan apabila individu tersebut memiliki ciri-ciri khusus di dalam perkembangannya dan terlihat berbeda dari perkembangan secara normal. Penyimpangan perkembangan tersebut dapat berbentuk penyimpangan intelegensi, yaitu intelegensi di bawah normal yang dikenal dengan individu reterdasi mental, atau intelegensi di atas normal yang dikenal individu superior dan gifted.

Anak berkebutuhan khusus merupakan istilah yang dipergunakan bagi individu yang memiliki karakteristik tertentu dan terlihat berbeda dengan anak lain. Kenyataanya secara 
perundangan dan wacana yang berkembang dewasa ini nampaknya istilah tersebut perlu ditinjau kembali.Undang-Undang Sistem Pendidikan Nasional (UUSPN) yang terbaru, terdapat istilah baru yang tadinya Pendidikan Luar Biasa telah diganti dengan Pendidikan Khusus. Ini mengandung konsekuensi terhadap penggunaan istilah baik kelembagaan maupun subyek peserta didik. Demikian pula halnya dengan wacana yang berkembang secara intenasional tentang peristilahan anak berkebutuhan khusus, yang dewasa ini sering disebut dengan istilah special needs educational children atau anak dengan kebutuhan pendidikan khusus.

\section{Bimbingan dan Konseling}

Bimbingan dan konseling terdiri dari 2 kata kerja yang berbeda. Bimbingan menurut Prayitno dan Amti (2004: 99) mengungkapkan pendapatnya bahwa bimbingan merupakan suatu proses kegiatan dalam rangka memberikan bantuan dalam yang dilakukan oleh seorang ahli, dalam hal ini dilakukan oleh konselor kepada klien baik individu maupun kelompok. Bantuan yang diberikan konselor kepada individu yang dimaksud adalah anakanak, remaja, orang dewasa, dan orangtua.bimbingan yang dilakukan konselor dilakukan agar klien yang dibimbing dapat mengembangkan kemampuan dalam dirinya, menjadi mandiri dan tidak bergantung pada oranglain dan mampu memanfaatkan seluruh potensi dirinya dan berkembang sesuai dengan norma-norma yang berlaku. Di buku terdahulunya Prayitno dan Amti (1994: 94) dikatakan bahwa dalam proses bimbingan klien dibantu oleh konselor agar klien dapat mengenali berbagai informasi yang terdapat pada dirinya, dalam hal ini baik potensi diri yang dapat dikembangkan maupun hal negatif yang dapat diminimalisir bahkan dihilangkan.

Sementara Winkel (2005: 27) mendefinisikan bimbingan menjadi 4 bagian antara lain: (1) bimbingan merupakan usaha yang dilakukan untuk melengkapi individu dengan pengetahuan, pengalaman dan informasi tentang dirinya sendiri, (2) bimbingan merupakan salah satu cara untuk membantu individu memahami dan mempergunakan secara efisien dan efektif berbagai kesempatan yang dimiliki untuk dapat mengembangkan pribadi dalam dirinya, (3) bimbingan merupakan jenis layanan yang diberikan pada individu-individu agar individu tersebut dapat menemukan pilihan, memantapkan tujuan secara tepat serta mampu menyusun rencana secara realistis, dan mampu menyesuaikan diri di manapun mereka berada sehingga mampu memuaskan diri di lingkungan mereka hidup, (4) bimbingan merupakan bagian dari proses pemberian bantuan atau pertolongan yang diberikan pada individu agar individu dapat memahami dirinya sendiri, dan mampu memahami dirinya 
sendiri dengan kebutuhan lingkungan, memilih, menentukan dan mampu menyusun rencana sesuai dengan kebutuhan dirinya dan tuntutan lingkungan.

Konseling menurut Prayitno dan Amti (2004: 105) merupakan suatu proses pemberian bantuan yang dilakukan secara professional oleh seorang ahli yang biasa disebut konselor dengan wawancara kepada individu yang disebut dengan klien yang memerlukan bantuan atau pertolongan karena memiliki masalah yang kemudian proses konseling bermuara pada teratasinya masalah yang dihadapi klien. Sejalan dengan itu, Winkel (2005: 34) mendefinisikan konseling sebagai serangkaian kegiatan paling pokok dari bimbingan dalam usaha membantu konseli/klien secara tatap muka dengan tujuan agar klien dapat mengambil tanggung jawab sendiri terhadap berbagai persoalan atau masalah khusus yang dihadapi. Bimbingan konseling yang diberikan pada orangtua anak usia dini berkebutuhan khusus adalah usaha yang dilakukan konselor untuk membantu individu/orangtua (klien) dalam rangka membantu anak agar dapat mengembangkan diri secara optimal sesuai dengan tahap perkembangan dan predisposisi yang dimilikinya (seperti kemampuan dasar dan bakat-bakatnya), berbagai latar yang ada (seperti latar belakang keluarga, pendidikan, status ekonomi), serta sesuai dengan tuntutan positif lingkunganya.

Ada beberapa tujuan dilakukan bimbingan konseling pada orangtua anak berkebutuhan khusus usia dini antara lain (1) agar orangtua memahami anak dengan baik, yaitu mengenal segala kelebihan dan kelemahan yang dimiliki berkenaan dengan bakat,minat, sikap dan perasaan dan kemampuannya, (2) agar orangtua memahami lingkungan anak yang meliputi lingkungan pendidikan di sekolah maupun lingkungan sosial masyarakat (3) agar orangtua mampu mengatasi masalah-masalah yang dihadapi dalam kehidupan sehari- hari, baik di sekolah maupun di luar sekolah ketika nanti anak siap sekolah. Selain itu alasan utama sesuai dengan tujuan pendididikan, yang tertulis pada Undang-Undang Sistem Pendidikan Nasional (UUSPN) tahun 1989 (UU No. 2/1989), yaitu terwujudnya manusia Indonesia seutuhnya yang cerdas, yang beriman, dan bertakwa kepada Tuhan Yang Maha Esa dan berbudi pekerti luhur, memiliki pengetahuan dan ketrampilan, kesehatan jasmani dan rohani, kepribadian yang mantap dan mandiri, serta rasa tanggung jawab kemasyarakatan dan kebangsaan.

Syaodah \& Agustin (2008) Dilihat dari tujuan dan materinya, lingkup layanan bimbingan yang dapat dilakukan pada orangtua dalam rangka mendidik dan membesarkan anak usia dini berkebutuhan khusus mengutamakan penekanan pada jenis kegiatan berikut ini (1) Bimbingan pribadi-sosial dimaksudkan untuk mencapai tujuan dan tugas perkembangan pribadi-sosial anak dalam mewujudkan pribadi yang mampu menyesuaikan diri dan bersosialisasi dengan lingkungan secara baik, (2) Bimbingan belajar dimaksudkan untuk 
mencapai tujuan dan tugas perkembangan pendidikan. Bimbingan belajar merupakan bimbingan yang diarahkan untuk membantu para anak dalam menghadapi dan memecahkan masalah-masalah belajar, (3) Bimbingan karier merupakan bimbingan untuk membantu anak dalam perencanaan, pengembangan dan pemecahan masalah-masalah karier, seperti pemahaman terhadap jabatan dan tugas-tugas kerja, pemahaman kondisi dan kemampuan diri, pemahaman kondisi lingkungan, perencanaan dan pengembangan karier, penyesuaian pekerjaan, dan pemecahan masalah-masalah karier yang dihadapi secara sederhana.

\section{KESIMPULAN DAN SARAN}

Anak berkebutuhan khusus dan keluarganya telah banyak terabaikan selama sekian tahun. Stereotipe dan perilaku dari masyarakat harus berubah dalam melihat keberagaman anak-anak di Indonesia.Anak-anak berkebutuhan khusus juga harus mampu belajar, menikmati hidup layaknya anak-anak lain, mandiri, produktif, dan berkembang sesuai potensinya, yang tentunya didukung melalui berbagai layanan, di antaranya melalui layanan bimbingan dan konseling. Anak-anak berkebutuhan khusus adalah individu yang unik. Mereka juga mempunyai hak untuk tumbuh dan berkembang sebagaimana anak-anak lainnya dan memiliki kebutuhan dasar yang sama. Ini merupakan tantangan bagi para konselor untuk berkolaborasi memenuhi kebutuhan-kebutuhan itu.

Pelayanan bimbingan dan konseling bagi anak berkebutuhan khusus akan amat erat kaitannya dengan pengembangan kecakapan hidup sehari- hari yang tidak akan terisolasi dari konteks. Oleh karena itu pelayan BK bagi anak berkebutuhan khusus merupakan pelayanan intervensi tidak langsung yang akan lebih terfokus pada upaya mengembangkan lingkungan perkembangan bagi kepentingan fasilitasi perkembangan konseli, yang akan melibatkan banyak pihak di dalamnya.

\section{ACUAN PUSTAKA}

Prayitno dan Amti, Erman. (2004). Dasar-Dasar Bimbingan dan Konseling. Jakarta: PT. Rineka Cipta.

Prayitno dan Amti, Erman. (1994). Dasar-dasar Bimbingan dan Konseling. Jakarta: PT. Rineka Cipta.

Syaodah dan Agustin. (2008). Bimbingan dan Konseling Untuk Anak Usia Dini. Jakarta: Universitas Terbuka.

Winkel, W.S. (2005). Bimbingan dan Konseling di Intitusi Pendidikan, Edisi Revisi. Jakarta: Gramedia. 